\author{
Н.В. Онучина, А.В. Кузнецовский, А.А. Воробьев, А.В. Филиппов \\ Филиал федерального государственного бюджетного учреждения \\ "48 Центральный научно-исследовательский институт» \\ Министерства обороны Российской Федерации, \\ 610000, Российская Федерация, 2.Киров, Октябрьский проспект, д. 119
}

\begin{abstract}
Поступила 27.04.2018 г. Принята к публикации 05.06.2018 г.
Сибирская язва является особо опасным зооантропонозным заболеванием, которое характеризуется тяжестью течения и высокой летальностью. Споры Bacillus anthracis обладают способностью длительно сохраняться в окружающей среде. На эндемичной территории сибиреязвенная инфекция может стать причиной массового заболевания людей и сельскохозяйственных животных. Кроме того, существует угроза применения биологических средств на основе возбудителя сибирской язвы террористическими организациями. Эпидемиологическое благополучие по сибирской язве напрямую зависит от вакцинации восприимчивых животных и населения групп риска. Многие из существующих сибиреязвенных вакцинных штаммов характеризуются низким уровнем продукции протективного антигена и высокой реактогенностыю. Перспективным направлением создания вакцинных препаратов нового поколения является клонирование отдельных детерминант иммуногенности сибиреязвенного микроба в гомо- и гетерологичных живых системах с целью создания высокоэффективных продуцентов протективного антигена B. anthracis. Цель работы заключалась в проведении исследований по получению рекомбинантного штамма Bacillus subtilis, продуцирующего протективный антиген сибиреязвенного микроба, перспективный для использования в технологии химических сибиреязвенных вакцин. В статье представлены результаты исследований по получению рекомбинантного штамма B. subtilis. На основе челночного вектора рНТ43 сконструирована плазмида рНТ43РА, содержащая ген pag синтеза протективного антигена сибиреязвенного микроба и стабильно функционирующая в клетках рекомбинантного штамма Amy21(pHT43PA) B. subtilis. В ходе исследований установлено, что микробные клетки рекомбинантного штамма Amy21(pHT43PA) B. subtilis обеспечивают продукцию иммунологически активного протективного антигена в количестве, не уступающем сибиреязвенным вакцинным штаммам. Полученные в ходе работ данные, а также безопасность, неприхотливость, изученность $B$. subtilis позволяют предложить данный рекомбинантный штамм для дальнейшего исследования в качестве продуцента сибиреязвенного протективного антигена, перспективного для использования в качестве химической составляющей сибиреязвенных вакцин.
\end{abstract}

Ключевые слова: Bacillus subtilis; ген pag Bacillus anthracis; клонирование; протективный антиген сибиреязвенного микроба; челночныц (B. subtilis/E. coli) вектор pHT43.

Библиографическое описание: Онучина Н.В., Кузнецовский А.В., Воробъев А.А., Филиппов A.В. Генетическое конструирование рекомбинантого итамма Bacillus subtilis, продуцирующего протективный антиген сибиреязвенного микроба // Вестник войск РХБ защцты. 2018. T. 2. № 2. C. 51-60. 
Н.В.Онучина, А.В. Кузнецовский, А.А. Воробьев, А.В. Филиппов

Сибирская язва - особо опасное зооантропонозное заболевание, характеризующееся тяжестью течения и высокой летальностью. Уникальная способность B. anthracis длительно сохраняться в окружающей среде вследствие чрезвычайной резистентности спор к воздействию внешних факторов приводит к накоплению в природе естественных резервуаров патогенного микроорганизма, десятки лет сохраняющих потенциальную опасность для человека и животных. В результате хозяйственной деятельности человека и природных катаклизмов горизонты почв, содержащие споры $B$. anthracis, часто оказываются вскрытыми, а споры - выброшенными на поверхность и рассеянными в окружающей среде. В условиях недостаточности или отсутствия профилактических мероприятий на эндемичной территории сибиреязвенная инфекция может стать причиной массового заболевания людей и сельскохозяйственных животных [1-4]. Более того, в последние годы появилась реальная угроза применения биологических средств на основе возбудителя сибирской язвы террористическими организациями. Как показал опыт ликвидации последствий биотеррористической атаки осенью 2001 г. в США, именно B. anthracis в первую очередь представляет интерес для террористов в качестве биологического поражающего агента в связи с его относительной доступностью, исключительной стойкостью и высокой летальностью при легочных формах сибирской язвы, приближающейся к $100 \%$ [5-7].

Один из факторов поддержания эпидемиологического благополучия по сибирской язве вакцинация восприимчивых животных и населения групп риска. Несмотря на несомненные достоинства предложенных в разные годы различными лабораториями мира сибиреязвенных вакцинных штаммов, многие из них, полученные классическими способами аттенуации вирулентных штаммов, нуждаются в улучшении характеристик, связанных с иммуногенностью, уровнем продукции протективного антигена (ПА) и реактогенностью [8].

Используемые в практике здравоохранения и ветеринарии аттенуированные вакцинные штаммы $B$. anthracis содержат в составе генома плазмиду $\mathrm{pXO1,} \mathrm{кодирующую} \mathrm{трехком-}$ понентный экзотоксин $[9,10]$. Протеолитически активированный протективный антиген, взаимодействуя с отечным и летальным факторами, образует токсичные комплексы, запускающие патогенетические механизмы инфекционного процесса $[11,12]$. Вместе с тем ПА сибиреязвенного микроба обладает выраженным иммуногенным эффектом. Поэтому одним из перспективных направлений конструирования профилактических препаратов является клонирование отдельных детерминант иммуногенности сибиреязвенного микроба в гомо- и гетерологичных живых си- стемах с целью создания высокоэффективных продуцентов ПА.

Впервые ген pag, детерминирующий синтез ПА, был клонирован M. Vodkin и S. Leppla [13] в штамме Escherichia coli. Уровень продукции ПА рекомбинантными клонами был на несколько порядков ниже значения, установленного для вакцинного штамма B. anthracis. В дальнейшем неоднократно предпринимались попытки клонирования гена pag в штаммах различных видов микроорганизмов: E. coli [14-16], S. typhimurium [17], L. casei [18], F. tularensis [19], B. subtilis [20-22] и B. anthracis [16, 21, 23]. Однако при создании стабильных генетических конструкций с высокой продукцией ПА сибиреязвенного микроба неизбежно возникают трудности, связанные с ограничением экспрессии гена pag за счет слабого собственного промотора, наличием позитивного (at $x A)$ и негативного (pagR) регуляторов, а также подверженностью белкового антигена протеолитической деградации [8]. Наиболее успешными оказались эксперименты по клонированию гена pag в гомологичной системе экспрессии - клетках B. subtilis. Работы по клонированию в B. subtilis даже без учета экологической безопасности этого микроорганизма чрезвычайно важны благодаря тому, что бациллы секретируют белки в культуральную среду. Таким образом, состыковав гетерологичные кодирующие последовательности с последовательностью сигнального пептида, можно добиться выхода из клетки продукта клонированного гена, конформационная и посттрансляционная модификации которого идентичны таковым при естественно происходящем инфекционном процессе. Эта способность позволяет получить исключительно высокий уровень продукции чужеродного белка без его внутриклеточного накопления.

Цель работы заключалась в проведении исследований по получению рекомбинантного штамма $B$. subtilis, продуцирующего протективный антиген сибиреязвенного микроба, перспективный для использования в технологии химических сибиреязвенных вакцин.

\section{Материалы и методы}

IIIтаммы микроорганизмов и плазмиды. В работе использовали вакцинные штаммы СТИ-1 B. anthracis и 55ВНИИВВиМ B. anthracis; штаммы Amy21 B. subtilis и ТOP10 E. coli, дефектные по синтезу протеаз и рестриктаз; челночный (B. subtilis/E. coli) коммерческий вектор для клонирования гетерологичных белков рНT43 («MoBiTec», США).

Питательные среды и реактивы. Штаммы микроорганизмов выращивали на плотной питательной среде, содержащей сердечно-мозговой экстракт (BHI, «Difco», СШA), в жидкой питательной среде (LB-бульон, NB-бульон, «Himedia», Индия). 
В экспериментах по определению ИД комбинантного ПА использовали белых мышей обоих полов массой от 18 до 20 г.

Плазмидную ДНК из штаммов $E$. coli, B. subtilis и B. anthracis в препаративных количествах выделяли с помощью коммерческих наборов для выделенияи очистки плазмид («Qiagen», СШІА). Для выделения ДНК из отдельных клонов использовали набор реактивов GeneJet ${ }^{\text {tu }}$ Plasmid Miniprep Kit («Fermentas», Литва).

Химический синтез праймеров для клонирования гена pag сибиреязвенного микроба осуществляли фосфоамидитным методом на автоматическом синтезаторе ACM-102-U (TOO «Биосан», г. Новосибирск). Очистку олигонуклеотидов проводили методом жидкостной хроматографии высокого давления.

Температурно-временные режимы ПЦР подбирали экспериментально. Амплификацию ДНК проводили методом ПЦР с синтезированными для клонирования гена pag праймерами в термоциклере МС-2 «Терцик» (ЗАО «НПФ ДНК-технология», Россия).

Продукты амплификации чистили с помощью набора MontageTM PCR Centrifugal Filter Devices фирмы («Millipore», США) в соответствии с рекомендациями производителя.

Реакции рестрикции и лигирования ДНК проводили в соответствии с рекомендациями фирмы-производителя ферментов («СибЭнзим», Россия).

Эффект рестрикции/лигирования подтверждали методом электрофореза в 1-1,5 \% агарозном геле в сравнении с контрольными препаратами ДНК.

Трансформацию микробных клеток штамма TOP10 E. coli проводили по методу T. Maniatis et al. с применением хлористого кальция [23]. Трансформационную смесь высевали на чашки Петри с ППС, содержащей ампициллин в концентрации $100 \mathrm{Mкг} \mathrm{cm}^{-3}$. Чашки инкубировали при температуре $(36 \pm 1){ }^{\circ} \mathrm{C}$ в течение 12-18 ч. Наличие вставки гена pag в векторе определяли в ПЦР с праймерами 5'-GGG GTA GAT CTC CAA GAA GTG ATT AA-3 и 5'-GGT CTG GAT CCG TAG GTC CAG CA-3'.

Секвенирование области вставки в $\mathrm{pHT} 43$ гена pag проводили на автоматическом секвенаTope ABI Prism 310 ("Applied Biosystems», CШA) c использованием набора «BigDue Terminator v3.1 Cycle Sequencing Kit».

Трансформацию клеток штамма Amy21 B. subtilis проводили по методике C. Anagnostopoulos и J. Spizizen [24]. Отбор трансформантов проводили с ППС, содержащей хлорамфеникол («Serva», Германия) в концентрации 5 мкг/мл.

Экспрессию рекомбинантного протективного антигена исследовали методом ИФА с помощью им- муноферментной моноклональной тест-системы для обнаружения протективногоантигена B. anthracis производства филиала ФГБУ «48 ЦНИИ» Минобороны РФ [25] и фотометра Columbus Pro («Тесаn», Австрия). Клеточные лизаты готовили методом ультразвуковой дезинтеграции с использованием дезинтегратора Labsonic 1510 (Германия). Культтуральную жидкость в объеме 5 мл центрифугировали в течение 3 мин при 8000 об/мин. Полученный осадок ресуспендировали в 0,5-1 мл буфера TE (pH 8,0). Дезинтеграцию проводили путем трехкратной обработки клеточной суспензии ультразвуком мощностью в 300 Вт и продолжительностью 20 с с перерывом в 30 c. Все операции проводили на льду. После дезинтеграции клеточные суспензии переносили в микроцентрифужные пробирки и центрифугировали в течение 3 мин при 8000 об/мин. Для дальнейших исследований в ИФА использовали надосадочную жидкость.

Белковый профиль рекомбинантных штаммов анализировали методом электрофореза в ПААГ. При подготовке образцов к электрофорезу к 1 мл бактериальной суспензии исследуемого клона, содержащей по стандарту мутности ГИСК им. Л.А. Тарасевича 10 млрд. м.к./мл добавляли 200 мкл раствора (20\% - сахарозы, $12 \%$ - додецилсульфата натрия, $30 \%$ - 2-меркаптоэтанола и $0,03 \%$ - бромфенолового синего), тщательно перемешивали пипетированием и прогревали на кипящей водяной бане в течение 5 мин. Для контроля полноты инактивации прогретую суспензию бактерий высевали на плотную питательную среду.

Аппаратное культивирование штамма Amy21(pHT43PA) B. subtilis проводили в аппарате МД-400. В качестве питательной среды для культивирования в аппарате использовали бульон Nutrient Broth («Himedia», Индия). Стерилизацию питательной среды проводили в аппарате МД-400 при $(121 \pm 1)^{\circ} \mathrm{C}(0,11 \mathrm{MПа)} \mathrm{в} \mathrm{течение} 15$ мин [26]. Хлорамфеникол вводили в питательную среду до конечной концентрации 5 мкг/мл непосредственно перед началом культивирования.

При засеве аппарата в качестве посевного материала использовали $(16 \pm 1)$ ч бульонную культуру штамма Аmy21(pHT43РA) B. subtilis, выращенную в бульоне Nutrient Broth («HiMedia», Индия) в присутствии хлорамфеникола ("Serva», Германия) в концентрации 5 мкг/мл при температуре $(36 \pm 1){ }^{\circ} \mathrm{C}$ и 100 об/мин. Качество посевного материала контролировали микроскопией окрашенных по Граму мазков.

В процессе культивирования в аппарате МД-400 поддерживали температуру $(36 \pm 1){ }^{\circ} \mathrm{C}$ и частоту вращения вала мешалки - 300 об/мин. По достижении бактериальной культурой оптической плотности $0,6-0,7$ о.е. при длине волны $\lambda=670$ нм в аппарат вводили раствор изопропил- $\beta$-D-тиогалактозида (ИПТГ) до конечной 
концентрации 0,001 М. Оптическую плотность исследовали фотометрически с помощью фотоэлектроколориметра КФК-2. После введения индуктора процесс вели до достижения бактериальной культурой оптической плотности $(1,05 \pm 0,05)$ о.е. и вводили в аппарат формалин до конечной концентрации $(0,05 \pm 0,015) \%$.

Процесс приготовления концентрированного ПА осуществляли методом микрофильтрации и ультрафильтрации на установках «Сартокон-2». Техническую подготовку установок осуществляли в соответствии с регламентом производства вакцины сибиреязвенной комбинированной жидкой и сухой для подкожного применения (№ 862-99) [26].

Иммуногенность препарата рекомбинантного ПА определяли согласно П. 12.7.10 экспериментально-производственного регламента № 862-99. Исходный препарат рекомбинантного протективного антигена, сорбированного на геле гидроокиси алюминия, с пятикратным шагом разводили 0,9 \% раствором хлористого натрия. Каждым разведением в объеме 0,5 мл подкожно иммунизировали 10 белых мышей, десяти контрольным животным вводили 0,9 \% раствор хлористого натрия. Через 14 сут всех вакцинированных и контрольных животных заражали внутрибрюшинно в объеме 0,5 мл споровой суспензией сибиреязвенного вакцинного штамма СТИ-1 в дозе 250 млн спор. За животными наблюдали в течение 10 суток, ежедневно проводя выборку павших животных [26]. Иммуногенность рассчитывали по методу Кербера в модификации Ашмарина.

\section{Результаты и обсуждение}

На первом этапе исследований была определена стратегия получения рекомбинантного штамма B. subtilis, продуцирующего иммунологически активный протективный антиген сибиреязвенного микроба. Для клонирования была выбрана челночная векторная система на основе B. subtilis/E. coli pHT43 производства фирмы «MoBiТес» (США), схематически представленная на рисунке 1 [27].

Способность репликации данного вектора как в E. coli, так и в B. subtilis позволяет все работы по клонированию в его составе гетерологичных генов провести на кишечной палочке, а слитая с последовательностью Pgrac промотора последовательность сигнального пептида $\alpha$-амилазы (SamyQ) позволяет секретировать транслируемый белок за пределы клеточной стенки сенной палочки.

С учетом сайтов рестрикции полилинкера вектора рНТ43 для амплификации и последующего клонирования гена pag сибиреязвенного микроба была разработана пара праймеров. Нуклеотидные последовательности праймеров и их основные свойства представлены в таблице 1.

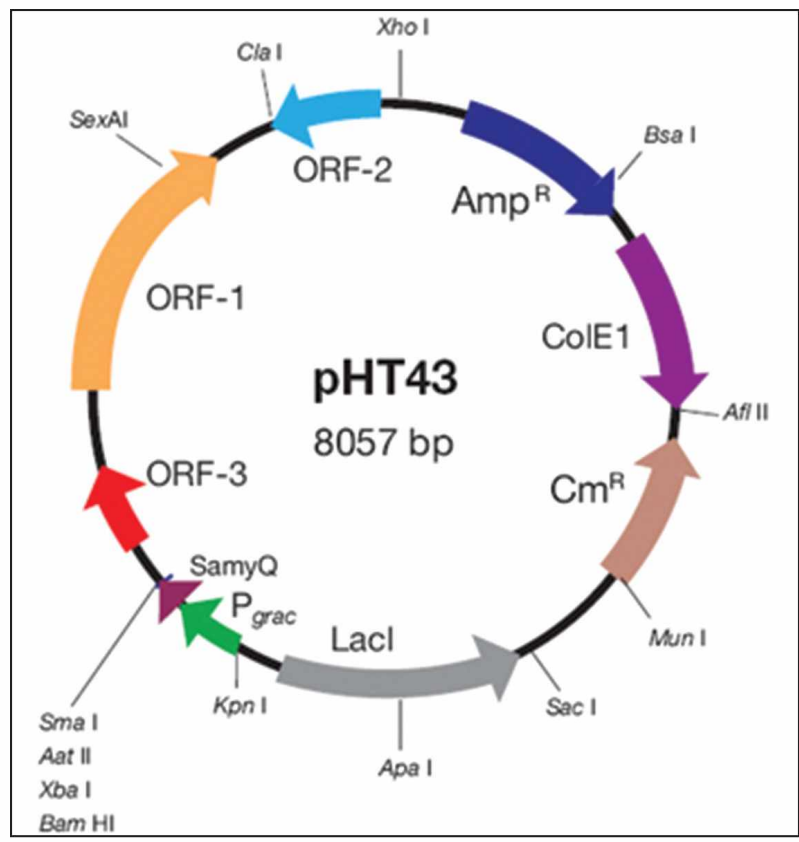

Рисунок 1 - Карта челночного вектора рНТ43 (AmpR - ген устойчивости к ампициллину; $C m R$-ген устойчивости к хлорамфениколу; Pgrac - ИПТГ индуцируемый промотор по muny экспрессии лактозного оперона; SamyQ - последовательность сигнального пептида а-амилазы B. subtilis; Smal, AatII, Xbal, BamHI- caŭmы рестрикции в составе полилинкера)

С использованием данных праймеров и высокоточной полимеразы Тaq SE в ПЦР с ДНК штамма СТИ-1 сибиреязвенного микроба был получен продукт амплификации ожидаемого размера, 2337 п.н.

Гидролиз вектора рНТ43 и амплификата гена $p a g$ рестриктазами BamHI и SmaI проводили последовательно, в связи с отличающейся их активностью в буферных растворах разной ионной силы. После обработки каждым ферментом препарат ДНК переосаждали этанолом с целью освобождения от мешающего буферного раствора [28]. Депротеинизацию растворов ДНК осуществляли путем экстракции фенолом и хлороформом [29].

Лигирование ДНК вектора и вставки проводили с использованием ДНК-лигазы фага Т4 (НПО «СибЭнзим», Россия) в буферном растворе производителя в течение 16 ч при $(16 \pm 1){ }^{\circ} \mathrm{C}$. На рисунке 2 представлены результаты лигирования ДНК вектора рНТ43 и гена pag.

Трансформацию микробных клеток штамма TOP10 E. coli проводили непосредственно смесью для лигирования. Выросшие трансформанты анализировали на наличие вставки гена pag в векторе рНТ43 методом ПЦР. Клоны E. coli, coдержащие ген протективного антигена, методом отпечатков пересевали на ППС с ампициллином в концентрации 100 мкг/мл и инкубировали при температуре $(36 \pm 1){ }^{\circ} \mathrm{C}$ в течение $18-24$ ч. Из 
Genetic Construction of Bacillus subtilis Recombinant Strain...

Таблица 1 - Последовательности праймеров для амплификации и клонирования гена pag B. anthracis и их основные свойства

\begin{tabular}{|c|c|c|c|c|}
\hline $\begin{array}{c}\text { Обозначение } \\
\text { праймера }\end{array}$ & $\begin{array}{c}\text { Нуклеотидная последовательность } \\
\left(5^{\prime} \rightarrow 3^{\prime}\right)\end{array}$ & $\begin{array}{c}\text { Длина } \\
\text { праймера, н }\end{array}$ & $\begin{array}{c}\text { Расчетная } \\
\text { температура } \\
\text { гибридизации, }{ }^{\circ} \mathrm{C}\end{array}$ & $\begin{array}{c}\text { Размер ожида- } \\
\text { емого ампли- } \\
\text { фиката, п.н. }\end{array}$ \\
\hline PagL & ACA AAA AGG ATC CCG TAT ATG AAAAAAC & 2012 & 2008 & ЮAP \\
\hline PagR & ATT TAA AAA TCC CCG GGA ATT ACC TTA TCC & $\begin{array}{c}\text { Саудовская } \\
\text { Аравия }\end{array}$ & KHP \\
\hline $\begin{array}{l}\text { Примечание. } \\
\text { Подчеркиванием выделены сайты узнавания рестриктаз BamHI и Smal для праймеров PagL } u \text { PagR coomвеmственно. }\end{array}$ \\
\hline
\end{tabular}

выросших колоний с помощью набора реактивов GeneJet ${ }^{\text {тм }}$ Plasmid Miniprep Kit («Fermentas», Литва) выделяли плазмидную ДНК. Правильность встраивания гена pag подтверждали путем рестрикции ДНК отобранных клонов эндонуклеазами рестрикции BamHI и SmaI. Для дальнейших исследований отбирали только клоны, плазмидная ДНК которых расщеплялась рестриктазами на фрагменты длиной около 8 и 2,5 т.П.н (ДНК вектора и вставки соответственно). Из каждого отобранного клона штамма ТОР10 E. coli выделяли плазмидную ДНК, которой трансформировали клетки штамма Аmy 21 B. subtilis [24]. Отбор трансформантов проводили с ППС, содержащей хлорамфеникол в концентрации 5 мкг/мл. Наличие гена протективного антигена у B. subtilis, как и в случае c E. coli, подтверждали методом ПЦР с праймерами к гену pag B. anthracis. Всего для дальнейших исследований было отобрано 16 клонов штамма Amy21 B. subtilis, несущих ген протективного антигена сибиреязвенного микроба.

На следующем этапе проводили лабораторное культивирование отобранных клонов рекомбинантного штамма B. subtilis, в ходе которого в ИФА оценивали уровень экспрессии ПА и способность к накоплению рекомбинантного белка внутри клеток и в культуральной жидкости. Культивирование исследуемых штаммов проводили в колбах вместимостью 250 мл под ватно-марлевыми пробками в шуттель-аппарате («УВМТ 12-250", Россия) при температуре $(36 \pm 1){ }^{\circ} \mathrm{C}$ и скорости вращения 250 об/мин. Для выращивания использовали NB-бульон («Himedia», Индия) с хлорамфе-

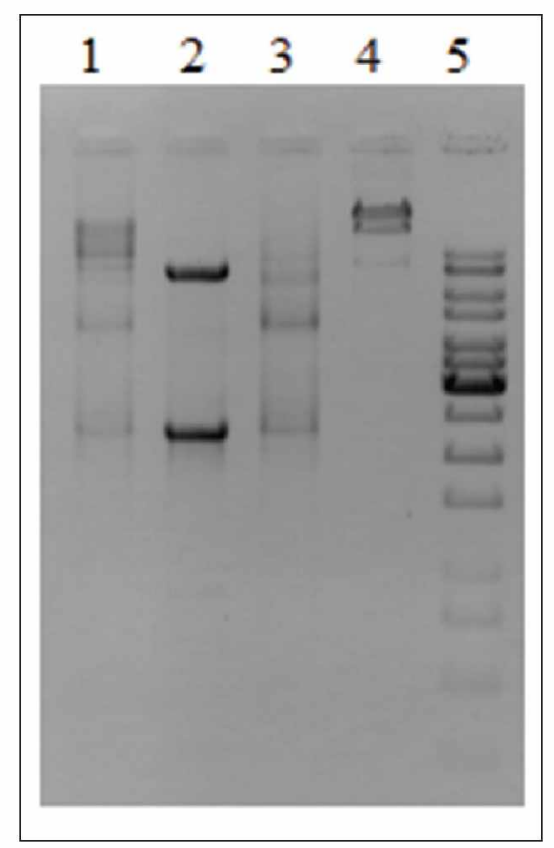

Рисунок 2 - Электрофорез в 1,5\% агарозном геле продуктов лигирования вектора рНТ43 и гена раg сибиреязвенного микроба (1 - продукт лигирования ДНК рHT43 и амплификата гена раg; 2 - смесь ДНК рНТ43 и гена раg (без лигазы); 3 - продукт лигирования ДНК амплификата гена pag "на себя»; 4 - продукт лигирования ДНК вектора рНТ43 «на себя»; 5 -маркер молекулярных масс ДНК 1 kb DNA Ladder) 
Н.В.Онучина, А.В. Кузнецовский, А.А. Воробьев, А.В. Филиппов

Таблица 2 - Результаты исследования лизатов и надосадочной жидкости микробных культур рекомбинантных клонов итамма Aту21 (pHT43PA) B. subtilis в иммуноферментном анализе

\begin{tabular}{|c|c|c|c|c|c|c|}
\hline \multirow{2}{*}{\multicolumn{2}{|c|}{ Исследуемая проба }} & \multicolumn{5}{|c|}{ Оптическая плотность исследуемых проб..., ОП ${ }_{429 н м}$, OE } \\
\hline & & \multirow{2}{*}{ до индукции } & \multirow{2}{*}{$\begin{array}{c}1 \text { ч после } \\
\text { индукции } \\
0,243\end{array}$} & \multirow{2}{*}{$\begin{array}{c}2 \text { ч после } \\
\text { индукции } \\
0,423\end{array}$} & \multirow{2}{*}{$\begin{array}{c}3 \text { ч после } \\
\text { индукции } \\
0,348\end{array}$} & \multirow{2}{*}{$\begin{array}{c}\begin{array}{c}4 \text { ч после } \\
\text { индукции }\end{array} \\
0,456\end{array}$} \\
\hline \multirow[b]{2}{*}{ Клон № 1} & Лизат & & & & & \\
\hline & $\begin{array}{c}\text { Надосадочная } \\
\text { жидкость }\end{array}$ & 0,171 & 1,577 & 2,256 & 2,689 & 2,127 \\
\hline \multirow[b]{2}{*}{ Клон № 2} & Лизат & 0,092 & 0,208 & 0,357 & 0,430 & 0,516 \\
\hline & $\begin{array}{c}\text { Надосадочная } \\
\text { жидкость }\end{array}$ & 0,187 & 1,043 & 1,538 & 1,905 & 1,734 \\
\hline \multirow[b]{2}{*}{ Клон № 3} & Лизат & 0,135 & 0,205 & 0,411 & 0,531 & 0,497 \\
\hline & $\begin{array}{c}\text { Надосадочная } \\
\text { жидкость }\end{array}$ & 0,076 & 1,640 & 2,146 & 2,286 & 1,983 \\
\hline \multirow[b]{2}{*}{ Клон № 4} & Лизат & 0,120 & 0,198 & 0,305 & 0,455 & 0,350 \\
\hline & $\begin{array}{c}\text { Надосадочная } \\
\text { жидкость }\end{array}$ & 0,080 & 1,345 & 1,980 & 2,225 & 1,850 \\
\hline \multirow{2}{*}{$\begin{array}{c}\text { 55ВНИИВВиМ } \\
\text { B. anthracis }\end{array}$} & Лизат & \multicolumn{5}{|c|}{ Не исследовали } \\
\hline & $\begin{array}{c}\text { Надосадочная } \\
\text { жидкость }\end{array}$ & 0,117 & 1,680 & 2,043 & 2,635 & 2,314 \\
\hline
\end{tabular}

нейшего изучения отобрали клон № 1 штамма Amy21(pHT43PA) B. subtilis, который характеризовался максимальными значениями оптической плотности проб в ИФА, что свидетельствовало о высоком уровне экспрессии сибиреязвенного ПА клетками данного клона.

Белковый профиль отобранного клона № 1 штамма Amy21(pHT43PA) B. subtilis, а также белковые профили контрольных штаммов исследовали на наличие белка методом электрофореза в ПААГ лизатов и надосадочной жидкости соответствующих бактериальных культур. Результаты белкового электрофореза представлены на рисунке 3.

Представленная на рисунке 3 картина белкового профиля показывает, что в пробах исследуемого рекомбинантного штамма Amy21(pHT43РA) B. subtilis, полученных в результате культивирования штамма в присутствии индуктора, содержится белок, схожий по молекулярной массе c белком, продуцируемым штаммом 55ВНИИВВиМ B. anthracis. В сравнении с маркером молекулярных масс белков данный белок обладает молекулярной массой около 80 кДа, что соответствует известной массе белка ПА сибиреязвенного микроба, равной 83 кДа.

На следующем этапе экспериментальных исследований было проведено длительное культивирование клона рекомбинантного штамма Amy21(pHT43PA) B. subtilis в течение 18 ч, в результате определили, что через $(2,5 \pm 0,5)$ ч после введения индуктора достигается максимальное содержание ПА в культуральной жидкости, а затем снижается до нулевого значения.

C учетом полученных данных по динамике накопления рекомбинантного ПА в культуральной жидкости нами был проведен

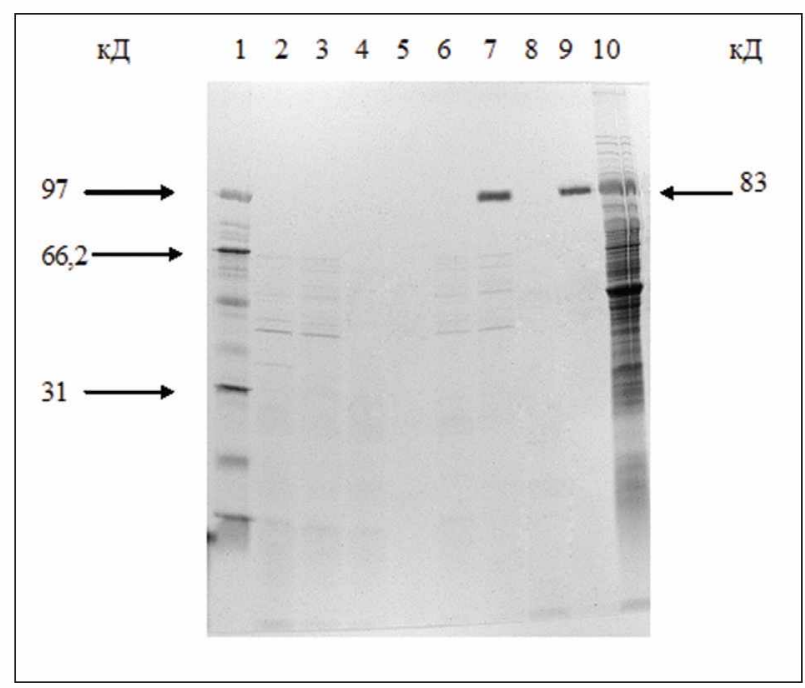

Рисунок 3 - Белковый профиль исследуемых рекомбинантного итамма Ату21 (рHT43PA)

B. subtilis и контрольных итаммов Аmу 21

B. subtilis $и$ 55ВНИИВВИМ B. anthracis

(1 -маркер молекулярных масс белков; 2, 3-лизаты бактериальной суспензии бесплазмидного итамма-реципиента Amy 21 B. subtilis без индуктораи в присутствии ИПТГ соответственно; 4, 5-супернатанты бактериальной суспензии бесплазмидного uтамма-реципиента Amy21 B. subtilis без индуктора и в присутстви ИПТГ соответственно; 6, 7-лизаты бактериальной суспензии рекомбинантного клона Amy21 (pHT43PA) B. subtilis в отсутствии индуктора и в присутстви ИПТГ соответственно; 8, 9 - супернатанты бактериальной суспензии рекомбинантного клона Amy21 (pHT43PA) B. subtilis в отсутствии индуктора и в присутствии ИПТГ

соответственно; 10-лизат бактериальной суспензии итамма 55ВНИИВВиМ В. anthracis в присутствии гидрокарбоната натрия. 
Генетическое конструирование рекомбинантого штамма Bacillus subtilis...

Таблица 3 - Результаты оценки на белых мышах иммуногенности препарата рекомбинантного протективного антигена, сорбированного на геле гидроокиси алюминия

\begin{tabular}{|l|c|}
\hline Штамм-продуцент ПА & Величина ИД , $_{\text {, усл. ед. ПА/мл }}$ \\
\hline Amу21(рНТ43РА) B. subtilis & 171 \\
\hline 55ВНИИВВиМ B. anthracis & 165 \\
\hline
\end{tabular}

цикл пробного культивирования штамма Amy21(pHT43РА) B. subtilis в аппарате МД-400. Из нативной культуры методом микрофильтрации и ультрафильтрации с использованием установки «Сартакон-2» был получен концентрированный препарат рекомбинантного ПА. Получение препарата сорбированного на геле гидроокиси алюминия рекомбинантного протективного антигена осуществляли в соответствии с регламентом производства вакцины сибиреязвенной комбинированной жидкой и сухой для подкожного применения (№ 862-99) [26].

В полученном препарате контролировали стерильность, pH, содержание общего азота, окиси алюминия и формальдегида по методикам, приведенным в Методических указаниях (МУК 4.1/4.2.588-96) [30].

Сорбированный концентрированный ПА полностью отвечал требованиям регламента:

стерильность;

$\mathrm{pH}(7,0 \pm 0,2)$;

содержание общего азота не более 0,4 мг в расчете на 10 мг окиси алюминия; миния;

содержание в 1 мл от 7 до 10 мг окиси алю-

содержание не более 0,001 \% формальдегида;

отсутствие неразбивающихся комков, хлопьев и посторонних включений.
Иммуногенность препарата ПА, приготовленного с использованием рекомбинантного штамма, оценивали в сравнении с иммуногенностью препарата, полученного в результате глубинного культивирования штамма 55ВНИИВВиМ B. anthracis в оптимальных для него условиях. Результаты определения ИД мышей представлены в таблице 3.

Представленные в таблице 3 результаты свидетельствуют о высокой иммуногенности препарата рекомбинантного ПА. ИД ПА - 171 усл.ед. ПА/мл, соответствует величине ИД ${ }_{50}$ сибиреязвенного вакцинного штамма 55ВНИИВВиМ B. anthracis - 165 усл.ед. ПА/мл.

Таким образом, в ходе проведенных работ установлено, что секретируемый штаммом Amy21(pHT43PA) B. subtilis протективный антиген сибиреязвенного микроба соответствует всем требованиям регламента производства комбинированной сибиреязвенной вакцины [26]. Учитывая полученные в ходе работ данные, а также безопасность, неприхотливость, хорошую изученность B. subtilis представляется целесообразным предложить данный рекомбинантный штамм для дальнейшего исследования в качестве продуцента сибиреязвенного ПА, перспективного для использования в качестве химической составляющей сибиреязвенных вакцин.

\section{Информаиия о конфликте интересов}

Авторы заявляют, что исследования проводились при отсутствии любых коммерческих или финансовых отношений, которые могли бы быть истолкованы как потенциалыный конфликт интересов.

\section{Сведения о рещензировании}

Статья прошла открытое рецензирование двумя рецензентами, специалистами в данной области. Рецензии находятся в редакции журнала.

\section{Список источников}

1. Бургасов П.Н., Черкасский Б.Л., Марчук Л.М. и др. Сибирская язва. М.: Медицина, 1970.

2. Бондарев В.П., Филиппов А.В., Дармов И.В. и др. Разработка иммуноферментной моноклональной тест-системы для обнаружения протективного антигена Bacillus anthracis // Проблемы особо опасных инфекций. 2007. Т. 93. С 66-69.

2. Онищенко Г.Г., Васильев Н.Т., Литусов Н.В. и др. Сибирская язва: актуальные аспекты микробиоло- гии, эпидемиологии, клиники, диагностики, лечения и профилактики. М.: ВУНМЦ МЗ РФ, 1999.

3. Онищенко Г.Г. Инфекционные болезни - важнейший фактор биоопасности // Эпидемология и инфекционные болезни. 2003. № 3. С. 4-16.

4. Кутырев В.В., Смирнова Н.И. Генодиагностика и молекулярное типирование чумы, холеры и сибирской язвы // Молекулярная генетика, микробиология и вирусология. 2003. № 1. С. 6-14.

5. Онищенко Г.Г., Федоров Ю.М., Тихонов Н.Г. и 
др. Противодействие биотерроризму как новая проблема эпидемиологии // Эпидемиология и инфекционные болезни. 2003. № 2. С. 4-6.

6. Inglesby T.V., Henderson D., Bartlett J.G. et al. Anthrax as a Biological Weapon. Updated recommendations for management // JAMA. 2002. V. 287. P. 2236-2252.

7. Pile J.C., Malone J.D., Eitzen E.M. et al. Anthrax as a Potential Biological Warfare Agent // Arch. int. Med. 1998. V. 158. P. 429-434.

8. Васильев Н.Т., Пименов Е.В., Кожухов В.В. и др. Перспективы создания сибиреязвенных вакцин нового поколения // Иммунология. 1999. № 3. С. 5-8.

9. Mikesell P., Ivins B., Ristroph J. Evidence for plasmid-mediated toxin production in Bacillus anthracis // Infect. Immun. 1983. V. 39. P. 371-376.

10. Okinaka R., Cloud K., Hampton O. et al. Sequence and organization of pX01, the large Bacillus anthracis plasmid harboring the anthrax toxin genes // J. Bacteriol. 1999. V. 181. P. 6509-6515.

11. Klimpel K.R., Molloy S.S., Thomas G., Leppla S.H. Anthrax toxin protective antigen is activated by a cell surface protease with the sequence specificity and catalytic properties of furin // Proc. Nat. Acad. Sci. USA. 1992. V. 89. P. $10277-10281$.

12. Leppla S.H. The anthrax toxin complex // Sourcebook of Bacterial Protein Toxins / Ed. Alouf J.F., Freer J.H. London: Academic Press, 1991. P. 277-302.

13. Vodkin M., Leppla S. Cloning of the protective antigen gene of Bacillus anthracis // Cell. 1983. V. 34. P. 693-697.

14. Алимов А.П., Павлов В.М. Патент РФ на изобретение № 2110575. Рекомбинантная плазмидная ДНК pro PF5, определяющая синтез капсульного антигена F1 возбудителя чумы и протективного антигена возбудителя сибирской язвы, и способ конструирования рекомбинантной плазмидной ДНК pro PF5 // Бюллетень № 13 от 10.05.1998.

15. Тедиков В.М., Добрица А.П. Клонирование и экспрессия детерминанты протективного антигена Bacillus anthracis в клетках Escherichia coli, Bacillus subtilis и Bacillus anthracis // Молекулярная генетика, микробиология и вирусология. 1993. № 2. С. 13-16.

16. Chauhan V., Singh A., Waheed S. et al.
Constitutive expression of protective antigen gene of Bacillus anthracis in Escherichia coli // Biochem. Biophys. Res. Commun. 2001. V. 283. P. 308-315.

17. Coulson N.M., Fulop M., Titball R.W. Bacillus anthracis protective antigen, expressed in Salmonella typhimurium SL3261, affords protection against anthrax spore challenge// Vaccine. 1994. V. 12. P. 1395-1401.

18. Zegers N, Kluter E., van Der Stap H. et al. Expression of the protective antigen of Bacillus anthracis by Lactobacillus casei: Towards the development of an oral vaccine against anthrax // J. Appl. Microbiol. 1999. V. 87. P. 309-314.

19. Pavlov V., Tedikov V., Mokrievich A. Cloning of pXOI and pag-gene of Bacillus anthracis in Francisella tularensis // International Workshop on Anthrax, 19-21 September 1995. Winchester, England. 1995. P. 108-109.

20. Baillie L. W. J., Moir A., Manchee R. The expression of the protective antigen Bacillus anthracis in Bacillus subtilis // J. Appl. Microbiol. 1998. Vol. 84. P. 741746.

21. Cohen S., Mendelson L., Altboum Z. et al. Attenuated nontoxinogenic and nonencapsulated recombinant Bacillus anthracis spore vaccines protect against anthrax // Infect. Immun. 2000. V. 68. P. 4549-4558.

22. Ivins B.E., Welkos S.L. Cloning and expression of the $B$. anthracis protective antigen in B. subtilis // Infect. Immun. 1986. V. 54. P. 537-542.

23. Barnard J.P., Friedlander A.M. Vaccination against anthrax with attenuated recombinant strains of Bacillus anthracis that produce protective antigen // Infect. Immun. 1999. V. 67. P. 562-567.

24. Клонирование ДНК. Методы / Под ред. Гловера Д. Пер. с англ. М.: Мир,1988.

26. Экспериментально-производственный регламент № 862-99 производства вакцины сибиреязвенной комбинированной жидкой и сухой для подкожного применения. Киров, 1999.

27. Bacillus subtilis Expression Vectors Product Information and Instructions, 2005.

28. Молекулярная клиническая диагностика. Методы / Под ред. Херрингтона С., Макги Дж. Пер. с англ. М.: Мир, 1999.

29. Маниатис Т., Фрич Э., Самбрук Дж. Молеку-

\section{Об авторах}

Филиал федерального государственного бюджетного учреждения «48 Центральный научно-исследовательский институт» Министерства обороны Российской Федерации. 610000, Российская Федерация, г. Киров, Октябрьский проспект, д. 119

Онучина Наталья Викторовна. Младший научный сотрудник научно-исследовательского отдела, канд. биол. наук. Кузнецовский Андрей Владимирович. Начальник научно-исследовательского управления, канд. биол. наук. Воробъев Алексей Анатольевич. Ведущий научный сотрудник научно-исследовательского отдела, д-р биол. наук.

Филиппов Алексей Владимирович. Заместитель начальника научно-исследовательского отдела - начальник группы научно-исследовательского отдела, канд. мед. наук.

Адресдля переписки: Онучина Наталья Викторовна; NIC48CNII@mil.ru 


\title{
GENETIC CONSTRUCTION OF BACILLUS SUBTILIS RECOMBINANT STRAIN, PRODUCING PROTECTIVE ANTIGEN OF ANTHRAX MICROBE
}

\author{
N.V. Onuchina, A.V. Kuznetsovsky, A.A. Vorobyov, A.V. Filippov \\ Branch Office of the Federal State Budgetary Establishment "48 Central Scientific \\ Research Institute" of the Ministry of Defence of the Russian Federation, \\ Oktyabrsky Avenue 119, Kirov 610000, Russian Federation
}

\begin{abstract}
Anthrax is a serious infectious disease with high mortality. The epidemiological security depends on the vaccination of susceptible animals and population at risk. But many of the existing anthrax vaccine strains possess low levels of protective antigen production and high reactogenicity. One of the most promising trends in production of new generation of vaccines is the cloning of particular determinants of immunogenicity of anthrax microbe for the creation of highly effective producers of Bacillus anthracis protective antigen. The aim of the article is to present the results of the study on the construction of recombinant Bacillus subtilis strain, producing B.anthracis protective antigen, promising for use in chemical anthrax vaccines technology. The pHT43PA plasmid containing the gene pag, providing the synthesis of protective antigen of the anthrax microbe and functioning stably in the cells of the recombinant strain Amy21(pHT43PA) of B. subtilis, was constructed on the basis of the shuttle vector pHT43. It is found out during the research, that the microbial cells of the recombinant strain Amy21(pHT43PA) of B. subtilis provide the production of immunologically active protective antigen in quantities, not inferior than anthrax vaccine strains. These data, as well as safety and simplicity of $B$. subtilis make it possible to continue the research of this recombinant strain as a producer of anthrax protective antigen, promising for use in vaccines production.
\end{abstract}

Keywords: Bacillus subtilis; gene pag Bacillus anthracis; cloning; protective antigen of the anthrax microbe; the shuttle (B. subtilis / E. coli) vector pHT43.

For citation: Onuchina N.V., Kuznetsovsky A.V., Vorobyov A.A., Filippov A.V. Genetic Construction of Bacillus subtilis Recombinant Strain, Producing Anthrax Protective Antigen // Journal of NBC Protecton Corps.2018. V. 2. № 2. P. 51-60.

\section{Conflict of interest statement}

The authors declare that the research was conducted in the absence of any commercial or financial relationship that could be construed as a potential conflict of interest.

Peer review information

The article has been peer reviewed by two experts in the respective field. Peer reviews are available from the Editorial Board.

\section{References}

1. Burgasov P.N., Cherkasskii B.L., Marchuk L.M. et al. Anthrax. Moscow Medicine, 1970. (in Russian).

2. Bondarev V.P., Filippov A.V., Darmov I.V. et al. Development of an immunoenzyme monoclonal test system for the detection of the protective antigen of Bacillus anthracis // Problems of Especially Dangerous Infections. 2007. T. 93. P. 66-69. (in Russian).

3. Onishchenko G.G., Vasil'ev N.T., Litusov N.V. et al. Anthrax: actual aspects of microbiology, epidemiology, clinic, diagnosis, treatment and prevention. Moscow, VUNMTs MZ RF, 1999. (in Russian).
4. Onishchenko G.G. Infectious diseases - the most important factor of biohazard // Epid. and Infect. Diseases. 2003. № 3. P. 4-16. (in Russian).

5. Kutirev V.V., Smirnova N.I. Genetic diagnostics and molecular typing of plague, cholera and anthrax // Molecular Genetics, Microbiology and Virology. 2003. № 1. P. 6-14. (in Russian).

6. Onishchenko G.G., Fedorov Iu.M., Tikhonov N.G. et al. Counteracting bioterrorism as a new problem in epidemiology // Epid. and Infect. Diseases. 2003. № 2, P. 4-6. (in Russian). 
7. Inglesby T.V., Henderson D., Bartlett J.G. et al. Anthrax as abiological weapon. Updated recommendations for management // JAMA. 2002. V. 287. P. 2236-2252.

8. Pile J.C., Malone J.D., Eitzen E.M. et al. Anthrax as a potential biological warfare agent // Arch. int. Med. 1998. V. 158. P. 429-434.

9. Vasil'ev N.T., Pimenov E.V., Kozhukhov V.V. et al. Prospects for the creation of a new generation anthrax vaccine // Immunology. 1999. № 3. P. 5-8. (in Russian).

10. Mikesell P., Ivins B., Ristroph J. Evidence for plasmid-mediated toxin production in Bacillus anthracis // Infect. Immun. 1983. V. 39. P. 371-376.

11. Okinaka R., Cloud K., Hampton O. et al. Sequence and organization of pX01, the large Bacillus anthracis plasmid harboring the anthrax toxin genes // J. Bacteriol. 1999. V. 181. P. 6509-6515.

12. Klimpel K.R., Molloy S.S., Thomas G., Leppla S.H. Anthrax toxin protective antigen is activated by a cell surface protease with the sequence specificity and catalytic properties of furin // Proc. Nat. Acad. Sci. USA. 1992. V. 89. P. 10277-10281.

13. Leppla S.H. The anthrax toxin complex // Sourcebook of Bacterial Protein Toxins / editors J.E. Alouf, J.H. Freer. Academic Press London. 1991. P. 277-302.

14. Vodkin M., Leppla S. Cloning of the protective antigen gene of Bacillus anthracis // Cell. 1983. V. 34. P. 693-697.

15. Alimov A.P., Pavlov V.M. The patent of the Russian Federation for invention No. 2110575. Recombinant plasmid DNA pro PF5, which determines the synthesis of the capsule antigen $\mathrm{F} 1$ of the plague and the protective antigen of the anthrax pathogen, and the method for constructing the recombinant plasmid DNA pro PF5. Bulletin No. 13 dated 10.05.1998. (in Russian).

16. Tedikov V.M., Dobritsa A.P. Cloning and expression of the determinant of the Bacillus anthracis protective antigen in cells of Escherichia coli, Bacillus subtilis and Bacillus anthracis // Molecular genetics, microbiology and virology. 1993. № 2. P. 13-16. (in Russian).

17. Chauhan V., Singh A., Waheed S. et al. Constitutive expression of protective antigen gene of Bacillus anthracis in Escherichia coli // Biochem. Biophys. Res. Commun. 2001. V. 283. P.308-315.

18. Coulson N.M., Fulop M., Titball R.W. Bacillus anthracis protective antigen, expressed in Salmonella typhimurium SL3261, affords protection against anthrax spore challenge // Vaccine. 1994. V. 12. P. 1395-1401.

19. Zegers N, Kluter E., van Der Stap H. et al. Expression of the protective antigen of Bacillus anthracis by Lactobacillus casei: Towards the development of an oral vaccine against anthrax // J. Appl. Microbiol. 1999. Vol. 87. P. 309-314.

20. Pavlov V., Tedikov V., Mokrievich A. Cloning of pXOI and pag-gene of Bacillus anthracis in Francisella tularensis // International Workshop on Anthrax, 19-21 September 1995. Winchester, England. 1995. P. 108-109.

21. Baillie L. W. J., Moir A., Manchee R. The expression of the protective antigen Bacillus anthracis in Bacillus subtilis // J. Appl. Microbiol. 1998. V. 84. P. 741-746.

22. Cohen S., Mendelson L., Altboum Z. et al. Attenuated nontoxinogenic and nonencapsulated recombinant Bacillus anthracis spore vaccines protect against anthrax // Infect. and Immun. 2000. V. 68. P. 45494558.

23. Ivins B.E., Welkos S.L. Cloning and expression of the B.anthracis protective antigen in B.subtilis // Infect. and Immun. 1986. V. 54. P. 537-542.

24. Barnard J.P., Friedlander A.M. Vaccination against anthrax with attenuated recombinant strains of Bacillus anthracis that produce protective antigen // Infect. and Immun. 1999. V. 67. P. 562-567.

25. Cloning DNA. Methods / Ed. Glover D. Translation from English. Moscow: Mir, 1988. (in Russian).

26. Experimental production schedule of production of anthrax vaccine combined liquid and dry for subcutaneous application № 862-99. Kirov, 1999. (in Russian).

27. Bacillus subtilis expression vectors product information and instructions, 2005.

28. Molecular clinical diagnosis. Methods/ Ed. Khyerrington S., Makgi J. Translation from English. Moscow: Mir, 1999. (in Russian).

29. Maniatis T., Frich E., Sambruk Dzh. Molecular cloning. Translation from English. Moscow: 1984. (in Russian).

30. MUK 4.1/4.2.588-96. Methods for monitoring medical immunobiological drugs administered to people. Moscow, 1996. (in Russian).

\section{Authors}

Branch Office of the Federal State Budgetary Establishment «48 Central Scientific Research Institute» of the Ministry of Defence of the Russian Federation. Oktyabrsky Avenue 119, Kirov 610000, Russian Federation.

Onuchina N.V. Junior Researcher of the Scientific and Research Department. Candidate of Biological Sciences.

Kuznetsovskiy A.V. Chief of the Scientific and Research Branch. Candidate of Biological Sciences.

Vorobyov A.A. Leading Researcher of the Scientific and Research Department. Doctor of Biological Sciences.

Filippov A.V. Deputy Chief of the Scientific and Research Department - Head of the Group of the Scientific and Research Department. Candidate of Medical Sciences.

Adress: Onuchina Natalia Victorovna; NIC48CNII@mil.ru 